\title{
GAMBARAN KEPATUHAN PASIEN MELAKSANAKAN INSTRUKSI SETELAH PENCABUTAN GIGI DI RSGM FK UNSRAT
}

\author{
${ }^{1}$ Indra Setiawan \\ ${ }^{2} \mathrm{Ni}$ Wayan Mariati \\ ${ }^{2}$ Michael A. Leman \\ ${ }^{1}$ Kandidat Skripsi Program Studi Pendidikan Dokter Gigi Fakultas Kedokteran \\ ${ }^{2}$ Program Studi Pendidikan Dokter Gigi Fakultas Kedokteran \\ Universitas Sam Ratulangi Manado \\ Email: setiawan.indra@yahoo.com
}

\begin{abstract}
Instruction after tooth extraction is about what to do and to avoid after tooth extraction which aims to prevent the disruption of wound healing process and any possible complications. This study aimed to know patients' obedience to the instructions after tooth extraction implemented in RSGM FK Unsrat and at respondents' houses. This study used mixed methods with a cross sectional design. There were 44 people as respondents obtained by using purposive sampling method. The results showed that some patients ignored instruction, as follows: drug use rules, bite the gauze for 30 minute- 1 hour, avoid hot, spicy, hard textured food and not touching the surgery site with tounge. Conclusion: The most ignored instruction by patient was to follow the drug consuming rules.
\end{abstract}

Keywords: instruction after tooth extraction, obedienced

\begin{abstract}
Abstrak: Instruksi setelah pencabutan gigi ialah instruksi mengenai hal hal yang sebaiknya dilakukan dan dihindari setelah pencabutan gigi yang bertujuan untuk mencegah terganggunya proses penyembuhan luka dan komplikasi yang mungkin dapat terjadi. Penelitian ini bertujuan melihat gambaran kepatuhan pasien melaksanakan instruksi setelah pencabutan gigi di RSGM FK Unsrat. Jenis penelitian ini ialah mixed method study dengan desain penelitian potong lintang. Penelitian dilakukan di RSGM FK Unsrat dan di rumah responden dengan jumlah responden 44 orang. Pengambilan sampel menggunakan metode purposive sampling. Data disajikan dalam bentuk diagram dan tabel berdasarkan distribusi frekuensi, serta beberapa pernyataan dari responden. Hasil penelitian menunjukan ditemukan beberapa instruksi yang diabaikan oleh pasien, seperti menaati aturan pakai obat, menggigit kapas atau kassa selama 30 menit-1 jam, menghindari makanan panas, keras, pedas dan tidak menyentuh-nyentuh luka dengan lidah. Simpulan: Instruksi yang paling banyak diabaikan oleh pasien ialah instruksi untuk menaati aturan pakai obat
\end{abstract}

Kata kunci: instruksi setelah pencabutan gigi, kepatuhan

Tindakan pencabutan gigi merupakan salah satu tindakan bedah mulut yang paling banyak dilakukan di rumah sakit dan puskesmas. Dokter gigi akan memberikan beberapa instruksi kepada pasien mengenai hal yang harus dilakukan dan dihindari setelah pasien menerima tindakan pencabutan gigi. Contoh instruksi yang diberikan setelah pencabutan gigi, yaitu: "apabila mendapatkan resep taatilah aturan pakainya”; "jika diberikan antibiotik, harus dihabiskan”; "gigit kapas atau kasa selama 30 menit sampai satu jam sesudah pencabutan”; “jangan menghisap daerah 
bekas pencabutan”; “jangan merokok"; dan, “jangan sering meludah". 1

Pasien wajib mengetahui dan mengikuti instruksi setelah pencabutan gigi, dengan tujuan menghindari kemungkinan terjadinya komplikasi setelah pencabutan dan terganggunya proses penyembuhan luka. Komplikasi yang dapat terjadi setelah pencabutan, yaitu: $d r y$ socket; perdarahan; rasa sakit; edema; infeksi; dan, trismus yang persisten. ${ }^{1,2}$ Dry socket disebabkan oleh kontaminasi bakteri, merokok, dan penyakit sistemik. ${ }^{3}$

Masyarakat yang pernah menerima tindakan pencabutan gigi memiliki sikap yang berbeda-beda terhadap instruksi setelah pencabutan gigi. Beberapa masyarakat mematuhi, dan yang lain mengabaikan instruksi dari dokter gigi. Sikap mematuhi instruksi pasien dipengaruhi oleh berbagai faktor, salah satunya pengetahuan. ${ }^{4}$

Pasien cenderung mematuhi instruksi setelah pencabutan gigi yang diberikan dengan nilai informasi atau pengetahuan yang tinggi, serta cara penyampaian instruksi yang baik dari dokter gigi. Pengetahuan dengan banyak aspek positif akan menumbuhkan sikap yang makin postif. Sikap positif tersebut akan menghasilkan perilaku yang sesuai dengan instruksi dari dokter gigi.

Berdasarkan data RISKESDAS tahun 2013, jumlah obat sisa yang disimpan oleh masyarakat Indonesia di perkotaan berjumlah $46,3 \%$ dan $27,6 \%$ dari seluruh obat yang disimpan merupakan obat antibiotik. $^{5} \quad$ Masyarakat sering tidak menghabiskan antibiotik yang diresepkan oleh dokter akibat pemahaman terhadap resistensi antibiotik yang rendah.

Sikap masyarakat terkadang mengabaikan beberapa instruksi setelah pencabutan gigi yang diberikan oleh dokter gigi. Terdapat beberapa perilaku masyarakat yang menghambat proses penyembuhan luka dan memungkinkan terjadinya komplikasi, misalnya merokok setelah pencabutan gigi, mengonsumsi alkohol, dan sering meludah setelah pencabutan gigi. (hasil wawancara pribadi penulis dengan beberapa masyarakat di kota Manado). Penelitian ini bertujuan untuk mengetahui gambaran kepatuhan pasien melaksanakan instruksi setelah pencabutan gigi di RSGM FK UNSRAT.

\section{METODE PENELITIAN}

Penelitian ini menggunakan mixed method, dengan pendekatan potong lintang Pengumpulan data kuantitatif dengan menggunakan check-list dan pendekatan kualitatif dengan menggunakan in-deph interview pada sepuluh responden serta observasi dengan rekaman video. Penelitian ini dilaksanakan pada tanggal 24 Februari10 Juli 2015.

Populasi penelitian yaitu pasien yang berkunjung ke RSGM FK UNSRAT dari 10 Juni-8 Juli 2015. Metode pengambilan sampel yang digunakan metode purposive sampling yaitu suatu pengambilan sampel yang dilakukan dengan berdasarkan dari kriteria inklusi dan eksklusi. Kriteria inklusi yaitu: pasien yang berumur 18-60 tahun; pasien yang dirawat dengan tindakan pencabutan gigi; pasien yang kooperatif dan setuju untuk menjadi subjek penelitian. Kriteria eksklusi yaitu pasien dengan gangguan bicara dan gangguan mental.

Variabel penelitian yaitu kepatuhan pasien melaksanakan instruksi setelah pencabutan gigi. Instrumen penelitian yang digunakan yaitu lembar check-list instruksi operator, panduan wawancara, kamera, dan perekam suara. Lembar check-list merupakan daftar instruksi setelah pencabutan gigi yang sebaiknya diberikan operator kepada pasien berdasarkan temuan peneliti pada beberapa literatur. Observasi pemberian instruksi dari operator kepada pasien dilakukan di RSGM FK Unsrat dengan menggunakan lembar check list, setelah empat sampai lima hari peneliti berkunjung ke rumah responden untuk wawancara. Data yang digunakan dalam penelitian ini disajikan dalam bentuk tabel, diagram dan narasi. Data dideskripsikan 
berdasarkan distribusi frekuensi dan dijabarkan untuk setiap instruksi dalam bentuk narasi.

\section{HASIL PENELITIAN}

Penelitian dilaksanakan di RSGM FK UNSRAT dan wawancara di rumah responden. Jumlah responden yang didapat selama penelitian berjumlah 44 responden. Hasil penelitian menunjukkan distribusi frekuensi responden berdasarkan umur dan jenis kelamin (Gambar 1 dan 2). Tabel 1 memperlihatkan instruksi yang diberikan operator kepada pasien setelah pencabutan gigi dan persentase kepatuhan serta ketidakpatuhan

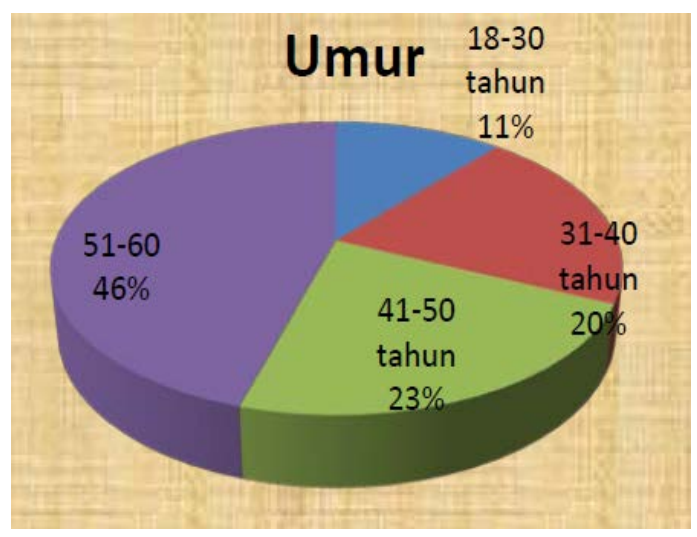

Gambar 1. Distrubusi frekuensi responden berdasarkan umur

\section{Jenis Kelamin}

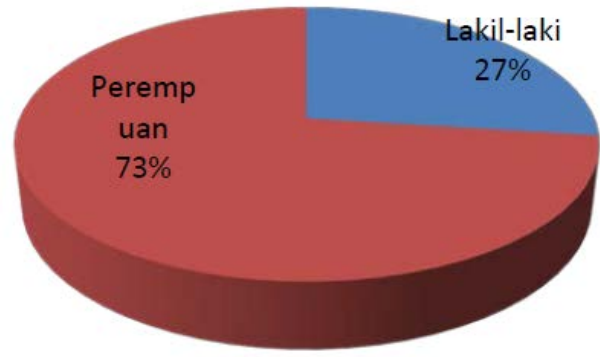

Gambar 2. Distribusi frekuensi responden berdasarkan jenis kelamin

\section{BAHASAN}

Hasil penelitian menunjukkan bahwa sebagian besar pasien yang menjadi responden selama bulan Juni 2015 paling banyak pasien paruh baya dengan usia 5160 tahun dengan presentase $46 \%$. Semua responden memahami dan masih mengingat instruksi yang diberikan karena jarak waktu wawancara yang dekat dengan waktu pasien menerima instruksi setelah pencabutan gigi.

Instruksi setelah pencabutan sendiri hanya akan dilakukan selama tiga sampai empat hari, perdarahan dan pembengkakan akan hilang dalam empat hari. sementara penyembuhan secara keseluruhan biasanya akan terjadi setelah tiga minggu. ${ }^{6}$

Tabel 1. Instruksi yang diberikan operator kepada pasien setelah pencabutan gigi dan persentase kepatuhan serta ketidakpatuhan

\begin{tabular}{|c|c|c|c|c|c|}
\hline No & Instruksi setelah pencabutan gigi & $\begin{array}{c}\text { Jumlah responden } \\
\text { yang menerima } \\
\text { instruksi }\end{array}$ & $\%$ & $\begin{array}{l}\text { Kepatuhan } \\
\text { (\%) }\end{array}$ & $\begin{array}{c}\text { Ketidak- } \\
\text { patuhan } \\
(\%)\end{array}$ \\
\hline 1 & Memberi tahu aturan pakai obat & 42 & 95,45 & 38 & 62 \\
\hline 2 & Mengigit kapas atau kassa selama 30 menit-1 jam & 38 & 86,36 & 92 & 8 \\
\hline 3 & $\begin{array}{l}\text { Tidak mengonsumsi makanan atau minuman panas } \\
\text { setelah pencabutan gigi }\end{array}$ & 31 & 70,45 & 94 & 6 \\
\hline 4 & Tidak mengonsumsi makanan keras dan pedas & 22 & 50 & 68 & 32 \\
\hline 5 & Tidak menyentuh-nyentuh luka dengan lidah & 18 & 40,9 & 83 & 17 \\
\hline 6 & Tidak banyak meludah setelah pencabutan gigi & 10 & 22,72 & 100 & 0 \\
\hline 7 & Tidak menghisap-hisap daerah luka pencabutan & 9 & 20,45 & 100 & 0 \\
\hline 8 & Tidak mengunyah di daerah luka pencabutan gigi & 6 & 13,36 & 100 & 0 \\
\hline 9 & Tidak berkumur kumur terlalu sering dan terlalu kuat & 5 & 11,36 & 100 & 0 \\
\hline 10 & Tidak merokok setelah pencabutan gigi & 3 & 6,81 & 100 & 0 \\
\hline 11 & Tidak beraktivitas berat setelah pencabutan gigi & 2 & 4,54 & 100 & 0 \\
\hline 12 & Tidak mengonsumsi alkohol setelah pencabutan gigi & 2 & 4,54 & 100 & 0 \\
\hline 13 & Tidak menyikat gigi pada daerah pencabutan & 1 & 2,27 & 100 & 0 \\
\hline
\end{tabular}


Instruksi setelah pencabutan sendiri hanya akan dilakukan selama tiga sampai empat hari, perdarahan dan pembengkakan akan hilang dalam empat hari. sementara penyembuhan secara keseluruhan biasanya akan terjadi setelah tiga minggu. ${ }^{6}$ Distribusi frekuensi berdasarkan jenis kelamin menunjukkan bahwa pasien yang menjadi responden paling banyak ialah pasien berjenis kelamin perempuan.

Berdasarkan hasil observasi ditemukan empat instruksi tambahan yang tidak termasuk dari sembilan daftar instruksi yang dibuat oleh peneliti. Pemberian instruksi pada beberapa pasien, ditemukan perbedaan informasi instruksi yang diterima oleh 38 pasien, yaitu: instruksi "Menggigit kapas atau kassa selama 30 menit-1 jam"; Terdapat dua orang diberikan instruksi "Menggit kapas atau kassa hingga pasien telah merasa tidak berdarah lagi"; dan, 14 orang diberikan instruksi tersebut tanpa diinformasikan lama waktu menggigit kapas. Peneliti juga menemukan terdapat perbedaan pemberian instruksi dari beberapa operator tentang aturan pakai dan cara penggunaan obat analgesik, sebagian menginstruksikan hanya dikonsumsi jika sakit dan sebagian menginstruksikan dikonsumi dua kali sehari.

Data tentang kepatuhan pasien melaksanakan instruksi setelah pencabutan gigi didapatkan dari hasil wawancara peneliti dengan pasien. Hasil penelitian menunjukkan bahwa instruksi untuk menaati aturan pakai obat merupakan instruksi yang paling banyak tidak dilaksanakan. Terdapat beberapa teori yang mempengaruhi kepatuhan pasien dalam program kesehatan, misalnya keseriusan penyakit, kompleksitas pengobatan, teori perilaku, komunikasi dokter dan pasien dalam hal memahami dan menerima, juga keyakinan rasional yang menimbang manfaat pengobatan. $^{7}$

Berdasarkan hasil penelitian, pasien tidak menghabiskan antibiotik karena pengetahuan tentang instruksi tersebut masih kurang. Pasien hanya menerima informasi untuk menghabiskan obat antibiotik tanpa mengetahui atau menerima informasi maksud dan tujuan instruksi tersebut. Pada telaah pustaka yang dilakukan Fatmah, hal yang perlu dilakukan dalam meningkatkan kepatuhan pasien dalam mengonsumsi obat ialah dengan memberikan informasi kepada pasien akan manfaat dan pentingnya kepatuhan terhadap instruksi yang diberikan serta memberikan informasi resiko ketidakpatuhan. ${ }^{8}$ Pasien tidak mengetahui resiko terjadinya resistensi obat jika tidak menghabiskan antibiotik yang diresepkan. Pasien berhenti minum obat dengan pertimbangan merasa diri sudah sehat dan rasa takut yang dirasakan pasien jika mengonsumsi obat terlalu banyak justru akan menimbulkan penyakit baru. Hal ini juga terjadi pada instruksi setelah pencabutan gigi lainnya, misalnya dalam memilih makanan yang akan dikonsumsi pasien setelah menerima tindakan pencabutan gigi. Sebagian besar pasien tidak menerima informasi mengenai resiko tidak mematuhi instruksi tersebut. Terdapat beberapa pasien mengonsumsi makanan apa saja yang tersedia di rumah tanpa mempertimbangkan instruksi yang diterima. Pasien beralasan tidak apa apa mengonsumi makanan keras, yang penting berhati-hati saat mengunyah jangan sampai terkena luka bekas pencabutan.

Pada penelitian yang dilakukan oleh Pratama tahun 2014 tentang gambaran kepatuhan dalam melaksanakan diet penderita diabetes menunjukkan bahwa, pasien tidak mematuhi anjuran diet pada penderita diabetes dengan yang dianjurkan karena kurangnya pengetahuan pasien mengenai diet yang baik bagi mereka. Pengetahuan tentang manfaat mematuhi instruksi memberi pengaruh besar pada pasien untuk melaksanakan instruksi setelah pencabutan gigi. Pengetahuan memiliki dua aspek, yaitu aspek positif dan negatif. Semakin besar aspek positif suatu pengetahuan maka akan menimbulkan 
sikap yang positif pula. Pemahaman yang baik dan positif dari manfaat instruksi dan resiko tidak mematuhi instruksi akan menumbuhkan sikap kepatuhan dari pasien. ${ }^{9}$ Sebagai contoh, pasien yang mengetahui bahwa mengonsumsi makanan panas setelah pencabutan gigi dapat meningkatkan pembengkakan luka pencabutan memiliki sikap yang lebih positif untuk mematuhi instruksi dibandingkan dengan pasien yang hanya mengetahui bahwa tidak boleh mengonsumsi makanan panas setelah pencabutan gigi tanpa mengetahui resiko ketidakpatuhan dari instruksi tersebut.

Sikap mematuhi instruksi juga dipengaruhi oleh pengalaman pasien. ${ }^{10}$ Ketidakpatuhan pasien dalam mematuhi instruksi didasari atas beberapa pengalaman sebelumnya yang menunjukkan bahwa resiko tidak mematuhi instruksi setelah pencabutan gigi belum tampak atau dirasakan oleh pasien. Misalnya, resiko resistensi antibiotik jika tidak menghabiskan obat antibiotik, atau pasien merasa tidak terjadi apa-apa saat mengonsumsi makanan panas, keras dan pedas setelah pencabutan gigi. Pasien tidak harus menunggu sampai benar-benar terjadinya komplikasi atau terganggunya proses penyembuhan luka hingga pasien mau melaksanakan instruksi, karena tujuan sebenarnya dari sebagian besar instruksi setelah pencabutan gigi merupakan langkah preventif terhadap hal tersebut. Kesalahpahaman ini mengakibatkan pasien menganggap remeh beberapa instruksi yang diberikan oleh dokter gigi, yang mungkin mengakibatkan terganggunya proses penyembuhan luka dan terjadinya komplikasi yang dapat terjadi setelah pencabutan gigi.

Pemberian instruksi operator kepada pasien mengenai instruksi setelah pencabutan gigi masih terbilang kurang, karena masih banyak instruksi yang tidak diberikan, hal ini terbukti dari hanya enam instruksi yang diberikan kepada kurang dari sepuluh orang responden. Dokter gigi memiliki peranan penting sebagai pemberi informasi dan pengetahuan dalam meningkatkan kualitas informasi yang diberikan kepada pasien, sehingga pasien mau lebih mematuhi instruksi yang diberikan. Perawatan kesehatan seperti tindakan pencabutan gigi yang hanya didasari diagnosa yang tepat, keahlian saat penanganan, serta pemberian obat yang benar tentunya belum cukup untuk menjamin keberhasilan dari terapi tersebut jika tidak diikuti dengan kepatuhan pasien melaksanakan instruksi setelah pencabutan gigi yang diberikan dokter gigi.

\section{SIMPULAN}

Hasil penelitian menunjukkan bahwa dari 44 pasien yang menjadi subjek penelitian, ketidakpatuhan terjadi hanya pada instruksi, menaati aturan pakai obat, menggigit kapas selama 30 menit - 1 jam, menghindari makanan panas, keras dan pedas, serta tidak menyentuh-nyentuh luka dengan lidah. Ketidakpatuhan paling banyak terjadi pada instruksi "menaati aturan pakai obat”, sedangkan instruksi yang paling banyak dipatuhi yaitu: "tidak merokok setelah pencabutan gigi”; “tidak mengonsumsi alkohol setelah pencabutan gigi”; "tidak beraktivitas berat setelah pencabutan gigi"; "tidak banyak meludah setelah pencabutan gigi”; "tidak menghisap-hisap daerah luka pencabutan gigi”; "tidak menyikat gigi di daerah pencabutan"; "jangan kumur terlalu sering dan kuat-kuat"; "tidak mengunyah di daerah luka pencabutan”.

\section{SARAN}

Berdasarkan kesimpulan penelitian di atas maka penulis mengajukan sebagai berikut:

1. Diharapkan bagi tenaga kesehatan di Rumah Sakit Gigi dan Mulut Universitas Sam Ratulangi Manado agar dapat meningkatkan kualitas dalam proses komunikasi dokter dan pasien serta memberikan pemahaman 
yang lebih baik lagi dalam memberikan instruksi setelah pencabutan gigi.

2. Disarankan kepada operator yang menangani kasus pencabutan gigi di Rumah Sakit Gigi dan Mulut Universitas Sam Ratulangi Manado untuk memberikan lembaran berisi instruksi setelah pencabutan gigi serta resiko tidak mematuhi instruksi yang bisa dibawa pulang pasien.

\section{DAFTAR PUSTAKA}

1. Pederson WG. Buku ajar praktis bedah mulut (1st ed.). Jakarta. Buku Kedokteran EGC; 2012. p. 36, 93-99.

2. Bakar A. Kedokteran gigi klinis (2nd ed.). Yogyakarta. CV Quantum Sinergis Media; 2014 p. 92-93.

3. Koerner KR. Manual of minor oral surgery for the general dentist. Australia. Asia Pty Ltd. Blackwell; 2006 hal. 7576,291.

4. Kesmas. Faktor faktor yang berpengaruh terhadap perilaku. [internet] Tersedia dalam
URL:http://www.indonesianpublichea lth.com/2014/07/masalah-kesehatandan-perilaku.html; 2014 diakses 12 Maret 2015.

5. RISKESDAS, RKD dalam nonkuning 2013. P. 74,76.

6. Chestnut IG, Gibson J. Clinical dentistry (3rd ed.). China. Elsevier, 2007; p.. 163.

7. Bastable SB. Perawat sebagai pendidik prinsip prinsip pengajaran dan pembelajaran. Jakarta. EGC; 2002 p.140

8. Laiatushifa SNF. Kepatuhan pasien yang menderita penyakit kronis dalam mengonsumsi obat harian [intenet] Tersedia dalam URL fpsi.mercubuana.ac.id diakses 3 Juli 2015

9. Saam Z, Wahyuni S. Psikologi keperawatan (2nd ed.). Jakarta. Rajawali Pers;2013. p. 61,66.

10.Gunarsa DS, Gunarsa SY. Psikologi keperawatan. Jakarta. BPK GM; 2008 p. 72. 